\title{
The Dead Sea Scrolls are opened to the public
}

\section{The Huntington Library's decision to give scholars access to the Dead Sea Scrolls unleashes a publicity storm.}

\begin{abstract}
$\mathrm{I}$ $\mathrm{n}$ what has been hailed in the general media as a "bold move," "plainly progressive, plainly correct," and the "equivalent to breaking down the Berlin Wall," William A. Moffett, director of the Huntington Library in San Marino, California, announced on September 22, 1991, that the library had a complete set of photographs of the Dead Sea Scrolls and that these rare documents would be made available immediately and without restriction. A flurry of publicity including articles on the front pages of the New York Times and the Los Angeles Times, numerous editorials, and a commentary by William Safire brought to the attention of the general public the Dead Sea Scrolls and the questions of intellectual freedom and access that they pose
\end{abstract}

\section{What are the Dead Sea Scrolls?}

As described by the New York Times and the Los Angeles Times, the Dead Sea Scrolls are comprised of some 800 manuscripts in Hebrew and Aramaic that were discovered by Bedouin shepherds between 1947 and 1956 in caves east of Jerusalem near the ruins of Qumran on the Dead Sea in what was then Jordan. These scrolls were said to be one of the most important archeological finds of this century. Dating back to 200 B.C. and into the first century A.D., the scrolls contain books of the Hebrew Bible as well as parchment and papyrus manuscripts chronicling the social and religious background of Judaism, Christianity, and Islam.

The New York Times explained that "nearly all the original scrolls are housed at the Rockefeller Museum in Jerusalem, with a few others on display at the Shrine of the Book in Jerusalem. Because of the risks of damage in war, several sets of photographs of the scrolls have been made and stored under the editor's control at Harvard, Hebrew
Union College in Cincinnati, Oxford University, and the Ancient Biblical Manuscript Center in Claremont, California."

Access to the scrolls is under control of the Israeli Antiquities Authority and the principal editors who were named by the Authority. According to the New

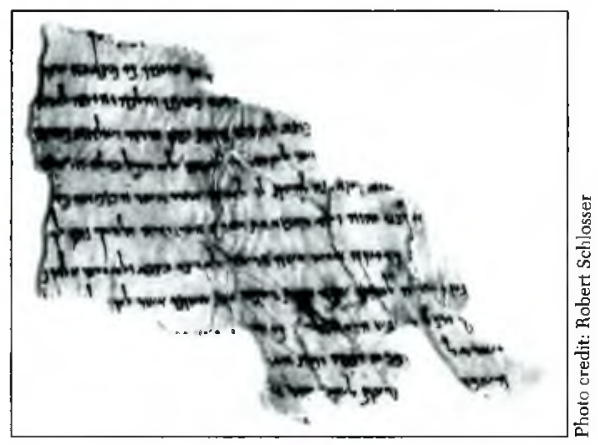

A scroll fragment from the Old Testament book of Deuteronomy, from the Huntington Library's photographic archive.

York Times, the three current principal editors are Eugene Ulrich, University of Notre Dame; Emmanuel Tov, Hebrew University in Jerusalem; and Emile Puech, Ecole Biblique in Jerusalem. Only one of the original team-Frank M. Cross of the Harvard Divinity School is still involved in the research.

\section{What does the Huntington have in its collection?}

As described by the Huntington, the library possesses "3,000 master photographic negatives taken of the original fragments, as well as duplicates 
made of the photographic archives at the Rockefeller Museum and the Shrine of the Book in Jerusalem, including photographs taken in the early years after the original Qumran discoveries and before the fading and deterioration that has subsequently affected some of the fragments. The collection is believed to include all of the so-called Dead Sea Scrolls in official repositories, including both unpublished and published manuscripts." The photographs were made in a series of trips to Israel beginning in 1980 by Robert Schlosser, a practitioner of the art of document photography, who was contracted by Elizabeth Hay Bechtel, president and founder of the Ancient Biblical Manuscript Center (ABMC) in Claremont, California, to do the work as a freelancer. (Coincidentally, Schlosser was and continues to be an employee of the Huntington Library.)

\section{How the' Huntington acquired the negatives}

The Huntington offers this explanation: In 1980 Elizabeth Hay Bechtel "persuaded Israeli officials to permit the photographic duplication of the materials held in Jerusalem since their seizure from the Jordanians in the war of 1967. As a philanthropist and an enthusiast for the preservation of early cultural artifacts, she was anxious not only to promote scholarly access but to ensure that the information contained in the scrolls would not be jeopardized by war or natural catastrophe. She both personally contributed to the financing the photographing of the manuscripts and oversaw the entire operation, arranging for one set of negatives to be deposited in the ABMC for purposes of research, and a master set to be deposited in secure storage elsewhere.

"A rupture between Mrs. Bechtel and the ABMC's executive vice president, James A. Sanders, resulted in the master set remaining in Mrs. Bechtel's possession under the aegis of the Preservation Council, a California non-profit corporation she created to carry forward her interests. In 1982 she negotiated an arrangement by which the master set of negatives was officially entrusted by the Preservation Council to the Huntington Library. In accordance with the agreement, following her death in 1987 and the subsequent dissolution of the Preservation Council, the photographs became the property of the library.

\section{What is the controversy?}

Scholars with the exclusive authorization from Israel to work with the scrolls were upset with the Huntington's decision. The Chicago Tribune attributes to Amir Drori, director of Israel's Antiquities Authority, the assertion that "easing access to records would violate the contract under which the fragments of scrolls were photographed in 1980. The photographs were given to several foreign institutions with the "written understanding that they would not be allowed to use them without our agreement. This is both a breach of contract and of ethics.' Early publication is unethical because only those scholars who dedicated years to deciphering the fragments should have first rights to release the material."

Scholars without access to the documents were generally pleased with the decision and felt that at last they would have equal footing with the "authorized" scholars. As quoted by the New York Times, Lawrence Schiffman, professor of Hebrew and Judaie studies at New York University, said: "Most will regard those who make this material available as Robin Hoods, stealing from the academically privileged to give to those hungry for the knowledge sacred in these texts. My students will now be able to work with the full set of manuscripts and write their dissertations without having to fear that they can be disproven by some unpublished text in the hands of a student of one of the editors."

Although the Huntington's announcement was widely acclaimed as a positive move for open access and intellectual freedom, the Chronicle of Higher Education reported that "the principle of open access intersects with sometimes-conflicting concerns over rights to intellectual property, ownership

\section{Humor \& prophecy precede the announcement}

The days and nights leading up to The Announcement, and those that followed immediately afterward, were not without stress. And somewhat as it must have been in wartime bunkers and command posts, humor was an essential antidote against the dreaded scourge of Taking Ourselves Too Seriously. Indeed, it was hard to take anything seriously when bewildered newsmen called to ask how we had come to have "dead sea squirrels," or TV anchorpersons expressed genuine disappointment at finding the scrolls were not in English.

And two nights before The Bomb went off, after a terrific meal with friends in a San Francisco restaurant, I broke open the proffered dessert treat and read with amazement the cryptic message on the little slip of paper: "A surprise announcement will set you free." Wow! It was enough to restore one's faith in Chinese fortune cookies. (But it was another week before I could be sure it didn't mean I was about to lose my job.)-William A. Moffett, Huntington Library 
of documents, and the need of librarians archives to balance their responsibilities to researchers, donors, and other institutions." [Ed. note: See the following commentary by Cathy Henderson, chair of ACRL's Rare Books \& Manuscripts Section for a closer look at these questions.]

\section{Why were the scrolls not available earlier?}

At the time the archive was deposited at the Huntington, the chief expectation of the institution was to provide a secure and stable environment for the preservation of the photographs, not to serve as a primary center for their study. The Huntington explained that "the agreement did provide for scholarly access and support of study, including reproduction and distribution of the collection "on discs' or other means, but as a duplicate set of negatives had been made for the ABMC in nearby Claremont, it is assumed that Biblical scholars would satisfy their research needs there-especially since the Huntington did not have the specialized reference materials that had been gathered for the use of Biblical scholars at the ABMC. Finally, given the schism between Mrs. Bechtel and her former colleagues in the ABMC, Huntington officials deliberately chose to avoid becoming involved in possible litigation between the two parties, and consequently took no action whatever to publicize the deposit of the archive. Although members of what is now called 'the cartel' [ed. note: those scholars with permission from the Israeli Antiquities Association to have access to the scrolls] were well aware of the collection's existence, they had access to their own resources and had little or no occasion to request permission to use it; scholars not in the cartel were generally not aware of its existence.

"The archive came quietly to the Huntington and for ten years has remained quietly in the darkness of its special vault whose construction Mrs. Bechtel had paid for in 1982. The photographs of the scrolls were never listed in the library's comprehensive roster of special collections. Despite the appearance of restrictions, curators have in fact never had occasion to turn down requests for access. Silence not regulations, did the trick."

\section{And why make the scrolls available now?}

When Moffett was appointed librarian at the Huntington in 1990 he began a review of the library's activities and collections and became aware of the photographic collection of the scrolls. The agreement between Bechtel and the Preservation Council had expired and Moffett felt that access to the photographic collection of the scrolls should be on the same basis as the rest of the library's holdings.
The Huntington's general policy on access is to "grant reader's privileges to any thoroughly qualified scholar, to provide copies of all of its materials for scholarly reference purposes under the 'fair use' doctrine, and to permit such persons to publish or reproduce for scholarly purposes any specified item among its holdings subject to copyright restrictions on those materials for which we do not control copyright.... No charge is made by the library for the use of materials for scholarly purposes; the library does not grant exclusive rights to any individual."

Moffett explained that his decision to announce the availability of the scroll photographs at the Huntington was influenced by several recent events. 1) Articles in the London Times about the Dead Sea Scrolls including one of that quoted a professor as saying the Oxford Center for Postgraduate Hebrew Studies would open its collection of scroll photographs and one that raised the issue of exclusivity; Moffett stated that he believed those"photographs were duplicates of the ones in the Huntington's collection. 2) A book advancing the argument that a conspiracy was keeping the manuscripts from academic scrutiny entitled The Dead Sea Scrolls Deception by Michael Baignet and Richard Leigh became a bestseller in England. Moffett said he felt that any change in the Huntington's position be established well before the book's scheduled American publication date in 1992.3) An indication that members of the cartel planned to pressure the Huntington into transferring the archive to their control and to insist that "no copies of them be retained hereafter in your care."

Moffett indicated that after consultation with his colleagues these events prompted him to plan for the Huntington's announcement that its collection of scrolls would be open and accessible. The announcement was scheduled to occur in conjunction with the airing of a PBS "Nova" special on the Dead Sea Scrolls in mid-October. Moffett moved up the date of the announcement after reports of a computer-generated text of the scrolls created by Professors Ben-Zion Wacholder and Martin Abegg of Cincinnati's Hebrew Union College made the news.

\section{How can one access the Huntington's collection?}

The Huntington has prepared the following statement: "Persons wishing to study at the Huntington must file a written application to be admitted as a reader. The request should indicate the applicant's institutional affiliation, if any, and his or her scholarly credentials, and the objective of admission. Letters of recommendation are often helpful, although not always necessary. Having been admit-

(Cont. on page 634) 
alike. It is behavior, as we have read, which "(although legal) should be avoided."

What mechanisms can the library profession employ to persuade an institution to behave differently? The Huntington Library has offered one example. What, beyond heightened public awareness and pressure, has been gained? The Huntington Library has released only photographic reproductions of the Dead Sea Scrolls. The increased availability of the reproductions does not obviate the need for scholars to have access to the originals because what is being produced, albeit on a schedule unsatisfactory to nearly all, is a scholarly edition of a text. Editors of texts need access to the originals of surviving manuscripts if their edition is to have authority. Running around the Israeli Antiquities Authority, the Rockefeller Museum in Jerusalem, and the scholars privileged to work with the original Dead Sea Scrolls may, in fact, be one way to jump the hurdles they have erected, but it may not help attain the ultimate goal of having democratic access to the original scrolls. The controlling parties need to be convinced that their methods are not conducive to even the chosen editors producing an authoritative text because they stifle the free flow of scholarly inquiry and discourse; but that may require persuasion of a different sort than the Huntington's bold move.

(Moffett cont. from page 632)

That policy has been consistently applied in succeeding years to the thousands of scholars who have drawn on the Huntington's fabled resources, as well as commercial and educational enterprises that have used its materials.

It is that same principle which is embedded in ACRL's and the Society of American Archivists' 1979 "Joint Statement on Access to Original Research Materials:"

"A repository should not deny access to materials to any person or persons, nor grant privileged or exclusive use of materials to any person or person, nor conceal the existence of any body of material from any researcher, unless required to do so by law, donor, or purchase stipulations."

Am I wrong in thinking that most of us simply accept that statement as a commonplace? Do any of us still contend with restrictions that mimic the Dead Sea Scrolls scandal? I sincerely hope not. But should any librarian or archivist find himself or herself in the position we found ourselves in at the Huntington this year, I trust that person will take heart from our experience. Be resolute! Take arms against even a sea of troubles-and by opposing, end them.
(Scrolls cont. from page 631)

ted, access will be dependent solely on the availability of study space and the number of other readers seeking access to the same materials. Use during some periods of the year is predictably very heavy, especially in the summer months.

"In the case of the scrolls archive, the reader will initially be expected to work from images on microfilm. In most cases it will not be necessary to go directly to the master negatives.

"If a person wishes to review the library's scrolls holdings at a distance, he or she can arrange to examine the microfilm set by asking his or her institutional library to secure it from the Huntington on ordinary interlibrary loan. (According to the library's customary practice there may be a modest charge to offset costs of copying, postage, and handling, but the Huntington does not propose to charge a fee for access.)"

\section{What is the current state of events?}

"I think it [the controversy] is over for us," commented Moffett. "The action should shift to the scholars." When asked if he's heard from the Israeli Antiquities Authority, Moffett replied that he's received an invitation from Emmanuel Tov of the Hebrew University in Jerusalem to attend a conference, tentatively scheduled for December 1991, to discuss the issues surrounding the scrolls. Authorized scholars and representatives of those institutions holding images of the scrolls are invited to attend. "The invitation is under consideration," said Moffett, who reported that the "response to the Huntington Library has been overwhelming. Not a single negative comment has come in. It's been a remarkable event to be involved in."-Mary Ellen $K$ Davis, editor and publisher, C\&RL News 